\title{
Echium amoenum from viewpoint of Avicenna: a brief review
}

\author{
Hossein Jafari, ${ }^{a}$ Roshanak Mokaberinejad, ${ }^{a^{*}}$ and Ehsan Raeis-Abdollahi ${ }^{b}$
}

aDepartment of Traditional Medicine, School of Traditional Medicine, Shahid Beheshti University of Medical Sciences Tehran, Iran.
bDepartment of Physiology, School of Medicine, Tehran University of Medical Sciences, Tehran, Iran.
${ }^{*}$ Correspondence to Roshanak Mokaberinejad (email: rmokaberi@gmail.com).
(Submitted: 21 Auguest 2018 - Revised version received: 18 September 2018 - Accepted:27 September 2018 - Published online: 26 December 2018)

Objectives The aim of this study was to compare the effects of Echium amoenum (Gol-e-gavzaban) in Iranian traditional medicine (ITM)
under the lens of Avicenna and modern medicine.
Results Echium amoenum has many therapeutic effects in ITM and modern medicine. E. amoenum is traditionally used as herbal tea in
Iranian traditional medicine (ITM) for conditions such as common cold, bronchitis, stress and fatigue. It also possesses diaphoretic, diuretic
and blood rectifying properties. Some of its effects such as general tonic, cardiotonic, diaphoretic, diuretic, sedative and antitussive has
been reported according to recent studies.
Conclusion There are many common characteristics about the pharmacological properties of E. amoenum in modern medicine and ITM, but
more research is needed to prove the safety and efficacy of the plant.
Keywords echium amoenum, iranian traditional medicine, avicenna, cardiotonic

\section{Introduction}

Echium amoenum, also named as Gol-e-gavzaban in Persian, from Boraginaceae family is one of the most commonly used medicinal plants, ${ }^{1}$ is distributed in the Northern region of Iran, as well as Europe and Mediterranean region. ${ }^{2}$ This annual herb has more than 100 genera and 2300 species and has long been used for many different diseases in the Iranian traditional medicine (ITM).

Echium amoenum is traditionally used as herbal tea in Iran for conditions such as common cold, bronchitis, stress and fatigue. It also possesses diaphoretic, diuretic and blood rectifying properties. The dried violet-blue petals of Iranian Borage are used as general tonic, cardiotonic, diaphoretic, diuretic, sedative and antitussive according to the ITM. In addition, Borago officinalis in Europe has been used for hyperactive gastrointestinal, respiratory and cardiovascular disorders. ${ }^{3}$ The similarity in clinical and pharmacological aspects of E. amoenum and B. officinalis is recognized. ${ }^{4}$

So far, several pharmacological activities of constituents of $E$. amoenum have been thoroughly evaluated which showed anti-anxiety, ${ }^{5}$ anxiolytic, ${ }^{6}$ analgesic and anti-depression, ${ }^{7}$ antiobsessive and compulsive, ${ }^{8}$ anticancer, ${ }^{9}$ anti-inflammatory, ${ }^{10}$ antimutagenic and cytotoxic, ${ }^{11}$ antioxidant and radical scavenging, ${ }^{12-14}$ antiviral, ${ }^{15}$ antibacterial, ${ }^{16}$ neonatal brain growth, ${ }^{17}$ and cardiovascular effects. ${ }^{18}$ Nowadays, various metabolites of E. amoenum, such as flavonoids, saponins, terpenoids, sterols and low amounts of essential oil, have been identified through phytochemistry studies. ${ }^{19}$

Uses of ancient knowledge in ethnopharmacology and related fields have prompted better understanding of progression and development of human plant utilization. ${ }^{20}$ Although the fields of molecular modeling, combinatorial chemistry, and other synthetic chemistry techniques have attracted a lot of attention by pharmaceutical companies and funding organizations, medicinal plants have remained a source of inspiration for finding new drugs, new drug leads, and new chemical entities. $^{21}$

In spite of notable achievements in drug discovery form medicinal plants, still many challenges await us. Natural product scientists such as pharmacognosists and phytochemists have to make advancements in the quality and quantity of compounds in the drug development to compete with other drug discovery projects. $^{22}$

Herbal therapy in Iran also have an old record and many manuscripts regarding this issue are left by great physicians such as Avicenna and Rhazes. ${ }^{23}$ E. amoenum is one of the important medicinal plants in the ITM. The profits of E. amoenum has been first learnt by Romans 300 B.C. Homer, the well-known Greek poet, assumed that the plant has positive effects on mood. ${ }^{8}$

In this study, we describe the traditional uses of E. amoenum and its therapeutic properties as defined by Avicenna in Book II, Canon of Medicine, Ketab Al-Adviah Al-Ghalbiah (heart drugs) or from current scientific studies.

Avicenna (980-1032 AD) was an outstanding Iranian physician who wrote the Canon of Medicine (in 1025 AD). This book was taught as a chief medical reference in Western and Eastern countries until the $17^{\text {th }}$ century. ${ }^{3}$

Avicenna believed that the drug has rarefying and cardiotonic effect and also useful for stomatitis, restlessness, melanotic disorder, palpitation, cough and roughness of upper respiratory tract. ${ }^{24}$ Avicenna also said in his other great book 'Al-Adviah Al-Ghalbiah' (heart drugs) that E. amoenum is a unique herbal drug for modulating of temperament, strengthening and exhilarating. ${ }^{25}$

Also Hakim Khorasani, one of the most famous physician of the ITM, has written in his book named Makhzan al Adviah about E. amoenum. He believed that this drug is useful for the treatment of cough, sore throat, pneumonia and some of pediatric febrile and eruptive disease. ${ }^{26}$

In this review article, the uses of E. amoenum as explained by Avicenna' books, Canon of Medicine, book of Al-Adviah Al-Ghalbiah, and various databases of the latest scientific studies are discussed and compared.

\section{Methods}

To compare the therapeutic effects of E. amoenum, an extensive search was performed through various databases such as 
PubMed, Scopus, ScienceDirect, and Google Scholar. The keywords for our search were: E. amoenum, Gol-e-gavzaban, Avicenna and "ibn sina". Then therapeutic and pharmacologic properties of this plant were gathered from 2000 up to 2018 . Unrelated citations were removed. We used Canon of Medicine in its original language (Arabic) to detect a true outcome. Only the Arabic versions were used because the English version did not clarify the particular effect obviously.

\section{Results}

\section{Comparative Evaluation in the Canon and Modern Medicine}

\section{Cardiotonic Effects}

Avicenna: "Two characteristics has been folded in this drug, so that no other medication could compete it in strengthening and exhilarating. One is its enhancing vitality properties and the other is its temperament feature" (Fig. 1). ${ }^{25}$

Avicenna: "It is rarefying and cardiotonic drug". ${ }^{35}$

The ITM is a medicinal system based on the humoral theory and it dates back to 10,000 years ago. ${ }^{27}$

According to the teachings of the Iranian medicine, if humor of sowda (black bile), changes to abnormal form (both in terms of quantity and quality), it can cause other pathological results, among which are sadness, anxiety and concern. This condition, named as melanotic disease, means that the disease is caused by sowda. Avicenna believed that E. amoenum, can remove these waste materials from the body and would indirectly lead to fright and happiness in the patient. ${ }^{24}$

Melancholia has been categorized as a kind of mental disease in the ITM and it forms as a result of an alteration in the quality of brain mizaj (temperament) that stops the person from rational thinking so that causes a depressed mood, terror, and mistrust without any clear cause. . $^{24,29,28}$

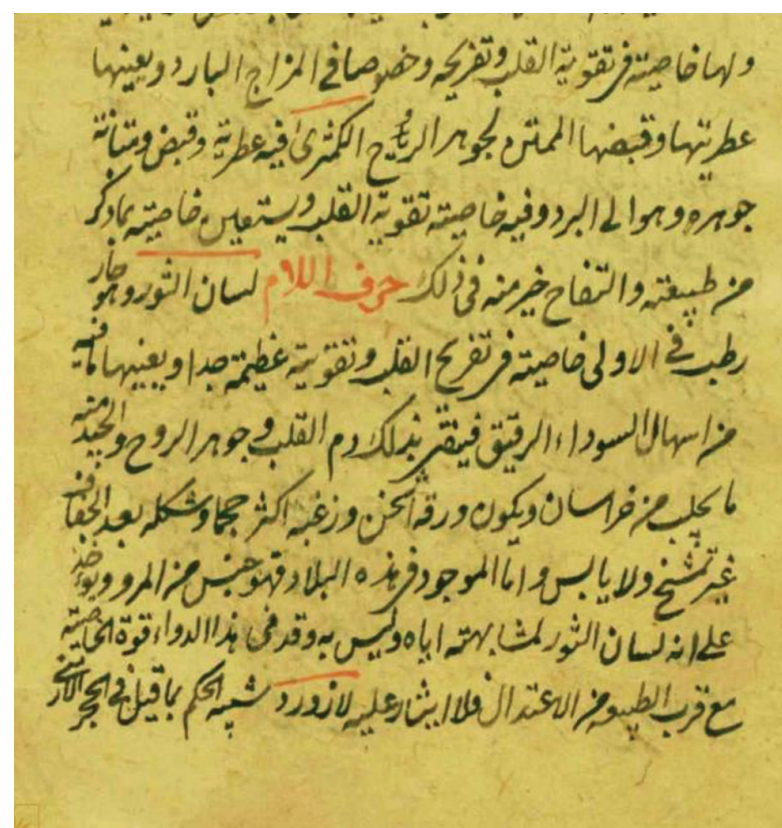

Fig. 1 A screenshot of Avicenna's book Al-Adviah Al-Ghalbiah (courtesy of the Library of the Parliament of Iran).
When we compare melancholia symptoms with major depression according to (DSM-4-TR) criteria, we found that this disorder have been categorized as one of the depression (mood) disorders. ${ }^{29}$

Nowadays, it is shown that Borage oil is effective on cardiac remodeling after myocardial infarction through an animal study on rats. Based on these results, borage oil reduces development of cardiac remodeling after myocardial infarction and congestive heart failure. ${ }^{30}$

Furthermore, it is largely acknowledged that emotional elements might impact physical function. This matter is lectured in comprehensive medicine as well as neuroscience. There are handy confirmations for the antagonistic effects of mental disorder on the physical health, for e.g. depressed mood and tension. ${ }^{31}$ Also a positive effect on treatment of major depression of E. amoenum is emphasized and it has been suggested for mood elevation.

Avicenna says: "The burnt borage cures stomatitis in children. It relieves burning of the mouth" ${ }^{3 .}$

Avicenna believed that E. amoenum is useful for aphthous stomatitis of children especially when burnt. ${ }^{24}$

Anti-inflammatory effects of $E$. amoenum examined in the J774.1A macrophage cell line with preparation of ethyl acetate, dichloromethane and hexane extracts derived from this plant and then probable cytotoxic effects were studied using MTT (a colorimetric assay for assessing cell metabolic activity) E. amoenum hexane extract revealed the maximum reduction in macrophage NO secretion compared to other

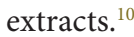

Avicenna: "It is good for treating restlessness, melanotic disease and palpitation". ${ }^{35}$

During an 8-week double-blind randomized clinical trial study on 37 patients with general anxiety disorder it was found that the aqueous extract of $E$. amoenum ( $500 \mathrm{mg}$ /day) together with selective serotonin reuptake inhibitors plus fluoxetine $(20 \mathrm{mg} /$ day $)$ or fluoxetine $(20 \mathrm{mg} /$ day $)$ plus a placebo had positive anxiolytic effect. ${ }^{3}$

Avicenna: "It is also useful in cough and roughness of wind-pipe specially when used in the form of a decoction with honey-water or sugar". ${ }^{35}$

It may be because of anti-inflammatory and immunomodulatory and radical scavenging effect of E. amoenum. ${ }^{4,10}$

Avicenna: "It is a mild purgative for melanotic humors". ${ }^{35}$

According to the ITM, repletion of redundant material in human body means "imtila" which can destroy normal function of cells and organs, thus leads to disease.

Purgative drugs can be effective on imtila both in prevention and treatment. ${ }^{3.5}$

Therapeutic effect of E. amoenum as described by Avicenna in Canon of Medicine and Al-Adviah Al-Ghalbiah are listed in Table 1.

\section{Other Therapeutic Effects}

\section{Antiviral Activity}

It is shown that aqueous extract of E. amoenum is effective against herpes simplex virus type I, when it is used with a concentration of $50-1000 \mu \mathrm{g} / \mathrm{ml}$ during 7 days. Significant activity appeared at the concentrations greater than $400 \mu \mathrm{g} / \mathrm{ml}$ by inhibiting virus replication. ${ }^{15}$ 
Table 1. Therapeutic effect of $E$. amoenum as described by Avicenna in Canon of Medicine and Al-Adviah Al-Ghalbiah. We used closest translation for each word

\begin{tabular}{ll}
\hline Effect or condition noted in Avicenna's two books & Current name of condition \\
\hline Mofarreh e-ghalb (exhilarating effect for heart) & Cardiotonic \\
Tawahhosh (useful for) & A disease like panic disorder \\
Sudawi disease (useful for) & Melancholic disease \\
Moshele-sowda ye-raghigh (purgative) & Expellant of diluted black bile \\
Mofarreh (enhancing vitality properties, useful for) & Mood elevator \\
Ghola (useful for) & Effective on aphtosostomatitis \\
Lahib-e-fam (useful for) & Oral cavity and tongue inflammation \\
So-al (useful for) & Cough \\
Khoshonat-e ghazib (useful for) & Hoarsness \\
\hline
\end{tabular}

\section{Antiparasitic Activity}

The antileishmanial effects of alcoholic and aqueous extracts of $E$. amoenum were demonstrated in a study on $\mathrm{BALB} / \mathrm{c}$ mice. In this study, the level of IFN- $\gamma$ were increased and parasite count decreased in the intervention group in comparison with the controls. ${ }^{15}$

\section{Antimicrobial Properties}

The aqueous extract of $E$. amoenum presented a concentration dependent antimicrobial activity against Staphylococcus aureus 8327 which was heat resistant. ${ }^{16}$

\section{Antioxidant and Radical Scavenging Activity}

An adjacent matching in pharmacological and clinical features of E. amoenum and B. officinalis (European type) is known. ${ }^{4}$

\section{Immonomodulatory Effects}

In one animal study on mice, it was concluded that the hydroalcoholic extract of E. amoenum can improve lymphocytic proliferation, but inhibits the proliferation of human antibodies. $^{34}$

\section{Anticonvulsant Effects}

Intraperitoneal administration of the methanol extract of E. amoenum at $6.25 \mathrm{mg} / \mathrm{kg}$ to mice before the injection of picrotoxin, produced an apparent rising in the latency of seizure and delayed the death time as compared with the control group. ${ }^{19}$

\section{Positive Effect on Benign Prostate Hyperplasia}

It is shown that the mixed hydroalcoholic solution of E. amoenum, Viola odorata and Physalis alkekengi is effective on benign prostate hyperplasia. Results declared that frequency of urination, intermittency, urgency, weak stream, straining and nocturia significantly decreased in the treatment group in comparison with the control group without any apparent side effect. ${ }^{35}$

\section{Toxicity and Teratogenicity}

The existence of pyrrolizidine alkaloids in E. amoenum could be a threat for hepatotoxicity and liver damage. Also, these kind of alkaloids have been displayed to have teratogenicity in pure situations. In one study with Ames test, it was found that a methanol extract $(0.25,0.5,0.75$, and $1.0 \mathrm{mg} / \mathrm{ml})$ from $E$. amoenum petals could be safe and non-mutagenic. However, during this study it was revealed that this plant has no mutagenic effects in usual daily doses. ${ }^{36}$ Another rat model study showed that aqueous extract of E. amoenum (100, 200, 400, $\mathrm{mg} / \mathrm{kg} /$ day) had no toxicity on liver during 1 and 2 weeks of treatment. ${ }^{19}$

\section{Conclusion}

As a common herbal plant, E. amoenum is widely used by traditional and conventional healers in Iran and its adjoining countries. Avicenna believed that no other medication could compete it in strengthening and exhilarating. There are many traditional and modern reports that confirm anti-inflammatory effects, antioxidant effects and antianxiolytic properties of this drug. It is probably because of active constituents of the plant, such as flavonoids, saponins, terpenoids, and essential oils. Therefore it may be probably a good option for prevention or treatment of a spectrum of inflammatory disorders specially heart diseases. It is apparent that more pharmacological and toxicological experiments and clinical trials are still required for the use of this herbal drug as a certified medicinal plant in clinical setting.

\section{Acknowledgement}

This article was based on a part of $\mathrm{PhD}$ thesis (Number 192) of Traditional Medicine, (Hossein Jafari) granted by School of Traditional Medicine, Shahid Beheshti University of Medical Sciences, Tehran, Iran (grant number 194). The authors would like to acknowledge Shahid Beheshti University of Medical Sciences cooperation and arrangements.

\section{Conflict of Interest}

There are no conflict of interest.

\section{References}

1. Zarshenas MM, Dabaghian F, Moein M. An overview on phytochemical and pharmacological aspects of Echium amoenum. Nat Prod J. 2016:6:285-291. Available from: https://www.ingentaconnect.com/ contentone/ben/npj/2016/00000006/00000004/art00005 () [cited 2018 Aug 19]
2. Abolhassani M. Antiviral activity of borage (Echium amoenum). Arch Med Sci. 2010;6:366-369. Available from: http://www.ncbi.nlm.nih.gov/ pubmed/22371772 [cited 2018 Apr 14].

3. Setayesh M, Zargaran A, Sadeghifar AR, Salehi M, Rezaeizadeh H. New candidates for treatment and management of carpal tunnel syndrome 
(CTS) based on Avicenna's teachings in the Canon of Medicine. Integr Med Res. 2018;7:126-135. Available from: https://www.sciencedirect.com/ science/article/pii/S2213422017302196 [cited 2018 Mar 12].

4. Zamansoltani F, Nassiri-Asl M, Karimi R, Mamaghani-Rad P. Hepatotoxicity effects of aqueous extract of Echium amoenum in rats. Pharmacologyonline. 2008;1:432-438. Available from: http://pharmacologyonline.silae.it/files/ archives/2008/vol1/42_Farzaneh.pdf [cited 2018 Feb 16].

5. Bakhshaei S. Phyto-pharmacological effect of nine medicinal plants as a traditional treatment of depression. J Appl Pharm. 2017:8:76-81. Available from: http://www.iioab.org/IIOABJ_8.S2_76-81.pdf (Supplement Issue: Biological Science) [cited 2018 Feb 15].

6. Gholamzadeh S, Zare S, Of MI-RJ. Anxiolytic effect of Echium amoenum during different treatment courses. Res J Biol Sci. 2008;3:176-178 Available from: http://docsdrive.com/pdfs/medwelljournals/rjbsci/2008/176-178.pdf (docsdrive.com [Internet]) [cited 2018 Feb 11]

7. Mansouri S. Inhibition of Staphylococcus aureus mediated by extracts from Iranian plants. Pharm Biol. 1999;37:375-377. Available from: http://www. tandfonline.com/doi/full/10.1076/phbi.37.5.375.6058 [cited 2018 Apr 15]

8. Sayyah M, Boostani H, Pakseresht S, Malaieri A. Efficacy of aqueous extract of Echium amoenum in treatment of obsessivecompulsive disorder. Prog Neuropsychopharmacol Biol Psychiatry. 2009:33:1513-1516. Available from: https://ac.els-cdn.com/ S0278584609002814/1-s2.0-S0278584609002814-main.pdf?_tid=spdffa3842cd-88ff-49c7-ba3f-1dca1466fdc7\&acdnat=1519620589_ e0b956d3a117e42f21ac5d3e77295cb6 [cited 2018 Feb 26].

9. Gonzalez C, Sanz J, Marcos G, Pita S, Brullet E, Saigi E. Borage consumption as a possible gastric cancer protective factor. Cancer Epidemiol Biomarkers Prev. 1993;2:157-158. Available from: https://www.researchgate.net/profile/Jose_ Miguel_Sanz-Anquela/publication/14812828_Borage_consumption_as_a_ possible_gastric_cancer_protective_factor/links/00b49517ae5226ff35000000 pdf (researchgate.net [Internet]) [cited 2018 Apr 15]

10. Naseri N, Kalantar K, Amirghofran Z. Anti-inflammatory activity of Echium amoenum extract on macrophages mediated by inhibition of inflammatory mediators and cytokines expression. Res Pharm Sci. 2018;13:73-81. Available from: http://www.ncbi.nlm.nih.gov/pubmed/29387114 [cited 2018 Mar 5].

11. Uysal H, Kızlet H, Ayar A, Taheri A. The use of endemic Iranian plant, Echium amoenum, against the ethyl methanesulfonate and the recovery of mutagenic effects. Toxicol Ind Health. 2015;31:44-51. Available from: http:// journals.sagepub.com/doi/10.1177/0748233712468019 [cited 2018 Apr 15]

12. Bekhradnia S, Ebrahimzadeh MA. Antioxidant activity of Echium amoenum Rev Chim. 2016;67:223-226. Available from: http://www.revistadechimie.ro

13. Safaeian $L$, Javanmard SH, Ghanadian M, Seifabadi S. Cytoprotective and antioxidant effects of Echium amoenum anthocyanin-rich extract in human endothelial cells (HUVECs). Avicenna J Phytomed. 2015;5:157-166. Available from: https://www.ncbi.nlm.nih.gov/pmc/articles/PMC4418065/ (ncbi.nlm. nih.gov [Internet]) [cited 2017 Dec 25].

14. Adel Pilerood S, Prakash J. Evaluation of nutritional composition and antioxidant activity of Borage (Echium amoenum) and Valerian (Valerian officinalis). J Food Sci Technol. 2014;51:845-854. Available from: http:// link.springer.com/10.1007/s13197-011-0573-z [cited 2018 Feb 16]

15. Farahani M. Antiviral effect assay of aqueous extract of Echium amoenum-L against HSV-1. Zahedan J Res Med Sci. 2013;15:46-48. Available from: http://zjrms.ir/browse.php?a_code=A-10-1602-1\&slc_ lang=en\&sid=1\&sw=Antiviral+effect [cited 2018 Apr 15]

16. Abolhassani M. Antibacterial effect of borage (Echium amoenum) on Staphylococcus aureus. Braz J Infect Dis. 2004;8:382-385. Available from: www.bjid.com.br [cited 2018 Mar 7].

17. Wainwright PE, Huang YS, DeMichele SJ, Xing H, Liu JW, Chuang LT, et al. Effects of high-gamma-linolenic acid canola oil compared with borage oil on reproduction, growth, and brain and behavioral development in mice. Lipids. 2003;38:171-178. Available from: http://doi.wiley.com/10.1007/ s11745-003-1048-2 [cited 2018 Apr 15]

18. Hamidi EM, Khaksari M, Hojabri K. The effects of aqueous extracts of Echium amoenum and citrus aurantiflia on blood pressure and heart rate before and after phynelephrine injection in rat. J. Kerman Univ. Med. Sci. 2014;18:349-357. Available from: http://eprints.kmu.ac.ir/22754/ (eprints kmu.ac.ir [Internet]) [cited 2018 Apr 15]
19. Mehrabani M, Ghannadi A, Sajjadi E, Ghassemi N, Shams-ardakani M. Toxic pyrrolizidine alkaloids of Echium amoenum Fisch. \& Mey. Daru. 2006;14(3):122-128

20. Heinrich M, Kufer J, Leonti M, Pardo-de-Santayana M. Ethnobotany and ethnopharmacology -interdisciplinary links with the historical sciences. 2006:107:157-160. Available from: https://www.sciencedirect.com/science/ article/pii/S0378874106002959 (Elsevier [Internet]) [cited 2018 Apr 15].

21. Balunas MJ, Kinghorn AD. Drug discovery from medicinal plants. Life Sci. 2005;78:431-441. Available from: http://www.sciencedirect.com/science/ article/pii/S0024320505008799 [cited 2018 Jan 10].

22. Butler MS. The role of natural product chemistry in drug discovery. J Nat Prod. 2004;67:2141-2153. Available from: http://pubs.acs.org/doi/ abs/10.1021/np040106y [cited 2018 Apr 15].

23. Changizi Ashtiyani S, Shamsi M, Cyrus A, Bastani B, Tabatabayei SM. A critica review of the works of pioneer physicians on kidney diseases in ancient Iran: Avicenna, Rhazes, Al-akhawayni, and Jorjani. Iran J Kidney Dis. 2011;5:300308. Available from: http://search.proquest.com/openview/e33d4e5dc7 4738409889d5f2b81f673b/1?pq-origsite=gscholar\&cbl=105769 (search proquest.com [Internet]) [cited 2018 Apr 15].

24. Sina I. Al-Qanun fi al-Tibb [The Canon of Medicine], Vol. 437; Alaalami Library, Beirut, 2005, p. 48-51

25. Borghei HR. The Book on Drugs for Cardiovascular Diseases. Nashre Ney, Tehran, 2009 (Imenshahidi et al., No Title. 2010)

26. Khorasani MHA. Makhzan al Advieh. Iran Bavardaran Press, Tehran, 2001 (Res Inst Islam Complement Med Iran Univ Med Sci).

27. Khodaei MA, Noorbala AA, Parsian Z, Targhi ST, Emadi F, Alijaniha F. Avicenna (980-1032CE): The pioneer in treatment of depression. Transylvanian Rev. 2017;25:4376-4389. Available from: https://scholar.google.com/ scholar?hl=en\&as_sdt=0,5\&q=6.+Araj+Khodaei+M,+Noorbala + AA, +Parsi an $+Z$, +Taheri+Tarighi+S, + Emadi $+F,+$ Alijaniha $+F,+$ Naseri+M, + Zargaran $+A$. +Avicenna+(980-1032CE)\%3A+The+pioneer+in+treatment+of+de-+ pression.+Transylvanian+Review+2017\%3B+ [cited 2018 Apr 16]

28. Kermani N. Sharhe Asbaab-o-Alaamaat of Samarghandi. Mohamad-Bagher Minaei, Mansour keshavarz. In: Describe the Etiology and Symptoms. Jalal al-Din, Qom, 2008.

29. Kaplan V, Sadock B. Pocket Handbook of Clinical Psychiatry. In: Arjmand M editor., $5^{\text {th }}$ ed.; Arjmand Publication, Tehran, 2010, pp. 210-215.

30. Maldonado-Menetti Jdos S, Vitor T, Edelmuth RC, Ferrante FA, Souza PR, Koike MK. Borage oil attenuates progression of cardiac remodeling in rats after myocardial infarction. Acta Cir Bras. 2016:31:190-197.

31. Veenhoven R. Healthy happiness: effects of happiness on physical health and the consequences for preventive health. J Happiness Stud. 2008;9:449-469. Available from: https://link.springer.com/content/ pdf/10.1007\%2Fs10902-006-9042-1.pdf [cited 2018 Mar 4].

32. Sayyah M, Siahpoosh A, Khalili H, Malayeri A, Samaee H. A double-blind, placebo-controlled study of the aqueous extract of Echium amoenum for patients with general anxiety disorder. Iran J Pharm Res. 2012;11:697-701. Available from: https://www.ncbi.nlm.nih.gov/pmc/articles/PMC3832167/ (ncbi.nlm.nih.gov [Internet]) [cited 2018 Apr 16].

33. Anonymous. Al-Qanun fil-Tibb (English Translation) (original AuthorAvicenna), Vol. 2. Department of Islamic Studies, New Delhi, 1998 (Jamia HAMDard;415_417).

34. Ghods R, Gharooni M, Amin G, Nazem E, Nikbakht Nasrabadi A. Hypertension from the perspective of Iranian traditional medicine. 2014;16:e16449. Available from: https://www.ncbi.nlm.nih.gov/pmc/articles/PMC4005451/ (ncbi.nlm.nih.gov [Internet]) [cited 2018 Apr 16].

35. Beiraghdar F, Einollahi B, Ghadyani A, Panahi Y, Hadjiakhoondi A, Vazirian $\mathrm{M}$, et al. A two-week, double-blind, placebo-controlled trial of Viola odorata, Echium amoenum and Physalis alkekengi mixture in symptomatic benign prostate hyperplasia (BPH) men. Pharm Biol. 2017:55:1800-1805.

36. Moosavi M, Jalali A, Kianipour F, Siahpoosh A, Farajzadeh-Shikh A. Assessing mutagenicity of methanolic exteract of borage flower (Echium amuenum) using ames bioassay. Iran South Med J 2014;17: 307-317. Available from: https://ismj.bpums.ac.ir/browse.php?a id =543\&slc lang=en \&sid=1\&printcase $=1 \& \mathrm{hbnr}=1 \& \mathrm{hmb}=1$ (ismj.bpums.ac.ir [Internet]) [cited 2018 Apr 16] 